\title{
Information Dissemination Strategies among Migrant Workers: A Conceptual Framework
}

\author{
Mohammad Fazli Baharuddin, Mohamad Noorman Masrek, Mohd Shamsul Mohd Shoid \\ Faculty of Information Management \\ Universiti Teknologi MARA \\ Shah Alam, Malaysia
}

\begin{abstract}
Seeking the information needs of migrant workers is very important in order for them to find and search for accurate sources. Thus, this paper aims to identify the information needs and information seeking behaviors of migrant workers in Malaysia and to develop information dissemination strategies among migrant workers. It will discuss in details on information needs and information seeking behaviors' of migrant workers that migrate in Malaysia which come from various country such Indonesia, Thailand, Philippines and others. A conceptual framework of information dissemination strategies based on information needs and information seeking behaviors' of migrant workers in Malaysia has been developed from the extensive literature and previous studies of the topics. A new model approach on information dissemination strategies among migrant workers is expected to be the major contributions of the study. It will be a platform of the migrant workers in Malaysia in order to identify their information needs and information sources.
\end{abstract}

\section{Introduction}

Malaysia is a competitive nation among the developing countries in Southeast Asia such as Indonesia, Philippines, Thailand and Myanmar. With good economic growth, has resulted in the entry of migrant workers into Malaysia increased dramatically. According to Malaysia Ministry of Home Affairs [1], number of migrant workers in Malaysia in 1999 is 409,660 compared in 2008 is $2,062,596$. In 1995, migrant workers comprise 35 percent of the labor force in Malaysia. In Seventh Malaysia Plan (1995 - 2000), Malaysia's total population increased by 2.3 percent a year, while foreign residents (non-citizens) covers 7.6 percent of the total working-age population in Malaysia, not including illegal foreign residents [2]. This show a large number and information needs of migrant workers should be studied and understand. The questions that need to be answered are the following: What are the information needs of migrant workers? How is their information seeking behavior? What are their sources of information? How to develop information dissemination strategies for migrant workers?
Information is an important factor in many aspects of life including work, education, health, and recreation. Migrant workers are a different group because they have specific information needs. Migrants are generally perceived to be information poor, meaning they face major challenges in finding and using information needed daily such as banking, rules, regulation, law, basic human rights, etc [3]. In fact, migrants need information constantly of all types like anybody else for the development of themselves and the environment in which they live. By development here it is meant the development of a person, the unfolding and realization of their creative potentials enabling them to improve their conditions of living through the use of resources available. A previous study by [4] showed that these have caused many problems amongst them, the low level of knowledge and skills of the prospective migrant workers themselves and the fact that the information they are given is generally not accurate, comprehensive or appropriate. The consequence is that the migrant worker becomes either directly or indirectly an object of commercialization and abuse.

Seeking the information of migrant workers is related to their information needs and information seeking behaviors. This is because in each of their daily work, the reliance on the information is very important. Most of migrant workers are very aware of their information needs. However most of them have difficulty in obtaining accurate information and thus fulfill their information needs. They do not know how to search and correct resources to be referred. Therefore, this paper will discuss in detail on information needs and information seeking behaviors of migrant workers in developing information dissemination strategies. The outcome of this paper will propose a new approach and strategies on information dissemination among migrant workers in Malaysia. Information behavior studies have the potential to establish the design of effective information services that incorporate the information needs, information seeking behavior and preferences for information sources of targeted users. With regards to academic literature, four research objectives are identified which are: 
- To identify the information needs of migrant workers in Malaysia

- To understand their information seeking behavior

- To identify their sources of information

- To develop an information dissemination strategies among migrant workers

\section{Information Dissemination Strategies: A Review of Literature}

A lot of thing related to the available information distribution channels like word of mouth, print media and ICT have already been discussed in this paper. Here, further consideration and analysis is given to these in an attempt to identify appropriate strategies for the dissemination of information to the migrant workers in Malaysia. Furthermore, a variety of information seeking behaviors' show in this discussion are using by migrant workers. Therefore, this paper is to identify information seeking behavior of migrant workers in developing information dissemination strategies. Figure 1 demonstrates the conceptual framework of information dissemination strategies based on information seeking behaviors' of migrant workers in Malaysia. Based on the framework, there are two independent variables which are Internal Factor and External Factor. Internal Factor includes information about finance, education level and information literacy among migrant workers while for External Factor includes peer/colleagues/social inclusion and facility condition. Besides, Information Dissemination Strategies will be the dependent variable as it generates the output of the study.

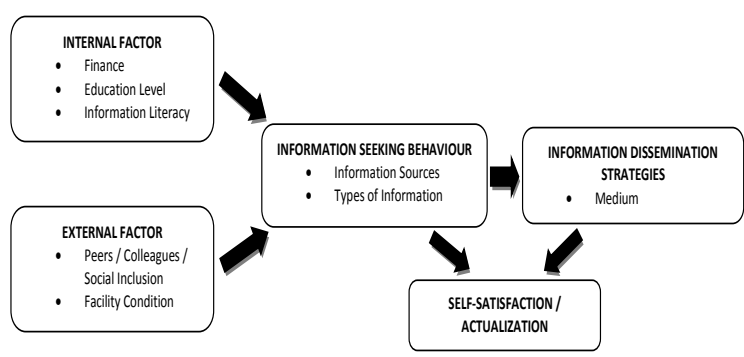

Figure 1. Conceptual Framework of Information Dissemination Strategies

The term migrant worker refers to a person who is engaged or has been engaged in a remunerated activity in a State of which he or she is not a national [4]. Migrant workers in Malaysia context is an employee of the originating from abroad who come to work in Malaysia for a certain period [3]. The arrival of migrant workers in Malaysia is to help meet the shortage of labour of the various economic sectors of the country. Their arrival, if not controlled, will decrease the local population's employment opportunities. However, the arrival of migrant workers was able to increase the country's output and reduce the rate of wages in the local labor market. Despite the benefits received by both the sending and receiving countries, many problems arise in the receiving country, Malaysia. The actual number of how many migrant workers in Malaysia right now is very difficult to identify. The number of legally to work with a passport and work permit certain can be identified. However, the number who came in informal or "illegal" or also called "illegal immigrants" is very difficult to estimate their numbers.

Table 1: Number of Migrant Workers in Malaysia by Country of Origin

\begin{tabular}{|l|c|c|c|c|c|}
\hline \multicolumn{1}{|c|}{ Year } & $\mathbf{2 0 0 4}$ & $\mathbf{2 0 0 5}$ & $\mathbf{2 0 0 6}$ & $\mathbf{2 0 0 7}$ & $\mathbf{2 0 0 8}$ \\
\hline $\begin{array}{l}\text { Country Of } \\
\text { Origin }\end{array}$ & Total & Total & Total & Total & Total \\
\hline Indonesia & $1,024,363$ & $1,211,584$ & $1,174,013$ & $1,148,050$ & $\begin{array}{c}1,085, \\
658\end{array}$ \\
\hline Bangladesh & 54,929 & 55,364 & 62,669 & 217,238 & $\begin{array}{c}316,4 \\
01\end{array}$ \\
\hline Philippine & 16,663 & 21,735 & 24,088 & 23,283 & $\begin{array}{c}26,71 \\
3\end{array}$ \\
\hline Pakistan & 1,156 & 13,297 & 11,551 & 16,511 & $\begin{array}{c}21,27 \\
8\end{array}$ \\
\hline Thailand & 5,463 & 5,751 & 13,811 & 18,456 & $\begin{array}{c}21,06 \\
5\end{array}$ \\
\hline Others & 367,516 & 507,507 & 583,077 & 621,267 & $\begin{array}{c}591,4 \\
81\end{array}$ \\
\hline TOTAL & $\mathbf{1 , 4 7 0 , 0 9 0}$ & $\mathbf{1 , 8 1 5 , 2 3 8}$ & $\mathbf{1 , 8 6 9 , 2 0 9}$ & $\mathbf{2 , 0 4 4 , 8 0 5}$ & $\begin{array}{c}\mathbf{2 , 0 6 2} \\
\mathbf{5 9 6}\end{array}$ \\
\hline \multicolumn{7}{|c|}{ Ministry of Home Affairs, Malaysia, 2009) } & \\
\hline
\end{tabular}

Refer to Table 1 above, in 2008 majority of migrant workers $(1,085,658: 52.6 \%)$ come from their country of origin Indonesia and followed by Bangladesh (316,401), Philippine (26,713), Thailand $(21,065)$ and Pakistan $(21,278)$. Meanwhile, number of migrant workers from other countries is $(591,481)$. This data collected by Ministry of Home Affairs, Malaysia in 2009.

The lack of information has been identified by researchers and organizations working in this field. However, a little research has been conducted so far on how to develop an appropriate information dissemination strategy especially tailored to the need and challenges of migrant workers. Much of the existing literature that examines the information needs of migrant populations focuses on what librarians and professionals think migrant's needs are [5]. Research is so important because migrant workers are in dire need of accurate information and reliable to undergo their daily activities. Information behavior studies have the potential to inform the design of an effective information services that incorporate the information needs, informationseeking and preferences for information sources of target users [6] [7].

According to [8] in his book "Information Need: A theory Connecting Information search to Knowledge Formation", the information need can be defined a factual situation in which there exists an 
inseparable inter-connection with 'information' and 'need'. It can be described that information need is a condition in which certain information contributes to the achievement of genuine purpose. If information needs can be considered a generic concept, then there are subsets which address information demands and information wants.

\section{Information needs of Migrant Workers}

Nowadays, Malaysia is in a situation where there are too many migrant workers. Approximately, the numbers of migrant workers who come in legally categorized, skilled and unskilled labor are about 3 million people [9] [10]. A study on information needs of Indonesian migrant workers conducted in Indonesia in 1999 reveals that causes for problems occurring are, amongst others, the low level of knowledge and skills of the prospective migrant workers themselves and the fact that the information they are given is generally neither accurate, comprehensive nor appropriate. The consequence is that the prospective migrant worker becomes either directly or indirectly an object commercialization [11]. Malaysia is a country that is rapidly developing and has development projects in almost all economic sectors. Malaysia experienced a labor shortage, especially in the agriculture, construction, factories and services. This is supported by [2] whereby Malaysia requires the workforce to help operate oil palm plantations, rubber plantations, paddy fields, fishing and animal husbandry. In case migrant workers are brought to Malaysia are not skilled in finding accurate and reliable information, there will be difficulty in carrying out a given job. In addition, there will be persecution and mistreatment against them by irresponsible parties. According to previous research by [4], one of the main reasons why Indonesian women are vulnerable for mistreatment and exploitation is a lack of information: a lack of access to information, a lack of availability of reliable information, and a lack of skills to make use of information. Information could prepare the migrant workers for what to expect, enable informed decision making, inform about process and procedures and therefore prevent human trafficking, and create awareness of rights and the possibility to get assistance. In short, information can empower the target group and lead to an improvement of their living and working conditions.

Research done by [12] mentioned that the areas in which immigrant needed information were multitudinous as well. These needs, however, crystallized into the following major areas:

- $\quad$ Educational information need: 40 percent;

- Health information needs: 5 percent;

- Employment information needs: 20 percent;
- How to deal with racism: 25 percent and

- Political information needs: 10 percent

According to [4], the information and knowledge needs during employment by migrant workers are as follows:

- Worker's rights

- Possibilities to end the contract before time

- That they are not the only person facing such problems

- That there are people out there who are willing and able to help

- What to do or where to go to find help

- How to travel back home

- How to bring the wages back home safely

Before developing new information dissemination strategies, it is important to consider potential challenges for the usefulness of channels and methods since they might form obstacles for a successful and sustainable implementation of a strategy. In determining what information is needed, people from the host country need to be aware of the cultural background and life experiences of the immigrants in order to ensure that appropriate and relevant information is provided. A lack of knowledge amongst host communities about the background and situations of new settlers can be seen as discrimination [13] and therefore a barrier in determining information needs.

\section{Information Sources of Migrant Workers}

Furthermore, sources of information become important for migrant workers for their knowledge about what they want. As mentioned before, most of the migrant workers are using the internet as the primary sources to find or searching for their needs. Many of those who use the Internet regularly said they do so primarily in order to send e-mail or use social networking platforms such as Facebook and web browser. Meanwhile, study conducted by [16] noted that migrants' own relatives and personal contacts, recruitment agents and brokers are an important source of information about work opportunities abroad. This findings is supported by [14] noted that from interviews with participants, they learned that their primary source of information were existing family, friends, or acquaintances who have already resided for months or years. Besides, immediate or fast access to a source of risk information, however, may not always affect information seeking. Previous study demonstrated that individuals can be selective about the source to which they respond irrespective of how quickly they can approach that source [15]. 


\section{Internal Factors of Information Seeking Behaviors}

Information seeking behavior refers to the way people search for and utilize information. In 2002, [17] described information behavior as the totality of human behavior in relation to sources and channels of information, including both active and passive information-seeking, and information use. According previous research, several factors have been identified as potential challenges to the migrant workers to meet and fulfill their information needs and seeking behavior since they might form obstacles for a successful and sustainable implementation of information dissemination strategies. First internal factor is financial background. The financial background of the prospective migrant worker determines the extent to which they can afford to travel, to buy books, or to go to an Internet Cafe. Therefore, it co-determines their chances to gain information. The majority of the migrants come from poor areas, many of them from remote rural regions [18] [4]. They have little income, barely any savings and have chosen to leave their families and work overseas because they hope for a better life. The recruitment system does not require the prospective migrant worker to spend any money in the first place, but to pay back at a later stage, which reduces the entry barriers to this kind of work. At the same time, the debts accumulated from the moment the decision is made make it impossible for the women to change their mind at a later stage.

Second internal factor is education level. It mentioned by [19] in their research done in Bangladesh that shows the number of illiterate in Bangladesh is still high and 41 percent of rural women completed their education at primary school only. According to[6] [8], the level of education determines the knowledge and the skills a prospective migrant worker has to make use of information, their ability to read and write, to understand complex correlations, to calculate costs and to operate certain technological devices to access information such as a telephone or a computer. Therefore, the level of education co-determines their chances to gain information and their ability to enhance personal knowledge. The poor find themselves trapped in a cycle of poverty. Since they are poor, the families cannot afford to send their children to school, but need them to work in order to support the family. Due to the resulting lack of education, the income opportunities of the children remain limited and therefore their chances to escape poverty and to improve their long term livelihoods remain limited. The poor do not have many chances to escape this vicious circle. Working overseas can be one way of achieving a sustained improvement of their living conditions; however, poverty and a lack of education may not only be a catalyst for seeking employment abroad, but it may also pose obstacles for a smooth process. A lack of skills and knowledge might cause problems before departure, during employment and on return. That was the obstacles faced by migrant workers in information searching [11]. A low level of education may result in reduced abilities to access information and to make use of it. Furthermore, difficulties might arise through lack of ability to judge the accuracy of the information given and therefore the risk of being deceived might increase [4].

Besides, information literacy skill is the last factor identified. Nowadays, the information simply published by advancement of internet technology. This creates information overload and assessments becomes more difficult. Finding by [20], through the Internet people believed that they would obtain be getting the most up-to-date information. The Internet provided people with the necessary links to further explore the information they were looking for. Therefore, people need information literacy skills to ensure that information is properly selected. Information literacy is the ability to access, evaluate, organize and use information from various sources [20]. This is the time to develop skills in information literacy especially among migrant workers because the creation of information becomes easier with development of technology. At present, information is not only created in paper form but also in electronic form. Thus, information literacy is prerequisite for participating effectively in an information society. The creation of an information society is a key to social, cultural and economic development of nations and communities, institutions and individuals in 21 st century and beyond [21].

\section{External Factors of Information Seeking Behaviors}

Meanwhile, facilities are influence the information search behaviors of migrant workers have been identified as external factors for instance internet technology. As discussed above, most of the migrant workers are using the internet as the primary sources. However, before developing an information dissemination strategy which might rely on information and communication technologies (ICTs), it is necessary to evaluate the availability of ICT for the migrant workers as well as their skills to use this technology and their ability to afford owning or using it. ICT includes fixed line telephones, mobile phones, radios, televisions, computers and internet access. These devices increasingly affect how we work and connect with each other, with whom they connect and how they make decisions, based on which information [12] [15]. The digital divide refers to the uneven distribution of information and communication technology (ICT) between and 
within nations [13]. This definition describes how the term is usually understood. In this sense, digital divide can be described as the gap that exists in most countries between those with ready access to the tools of information and communication technologies, and the knowledge that they provide access to, and those without such access or skills. This may be because of socio-economic factors, geographical factors, educational, attitudinal and generational factors, or it may be through physical disabilities [10]. These socio-economic factors may lead to a situation where certain groups of society do not have equal possibilities to gain or contribute information or knowledge and to derive benefits there from. Prevailing obstacles to make use of ICT 'include high rate of illiteracy, unawareness of the relevance of information, poverty and lack of infrastructural facilities.

\section{Conclusion}

This paper aims to identify the information needs of migrant workers in Malaysia and to develop information dissemination strategies among migrant workers. A conceptual framework of information dissemination strategies on information seeking behaviors' of migrant workers in Malaysia has been develop based on the extensive literatures in the topics and from the previous studies. Besides, current information dissemination strategies have been analyzed with regard to how appropriate they are to inform the target group effectively and alternative strategies. Moreover, numbers of interesting findings, some of which restate previous research carried out with migrant communities, while others highlight the need to take into description of different contexts. It was the intentions of this study to provide and create a new model and strategies on information dissemination among migrant workers in Malaysia. The outcome of the study is expected to be a platform of the migrant workers in Malaysia and assists them identify their information needs and identify their information sources.

\section{Acknowledgement}

Authors would like to extend our deepest gratitude to Ministry of Higher Learning Education of Malaysia for financing this project under Research Acculturation Grant Scheme (RAGS). We also dedicated to Research Management Institute (RMI) Universiti Teknologi MARA (UiTM) for helping in implementation of this project.

\section{References}

[1] Ministry of Home Affairs Malaysia, "Number of Foreign Workers in Malaysia by Country of Origin, 2009.
[2] C. H. Hassan, "Buruh asing di Malaysia: trend, kaedah, kesan, masalah dan cara mengatasinya," Journal of Southeast Asian Studies, vol. 14, 119-132, 2009. http://www.myjurnal.my/public/articledownload.php?id=321

[3] D. H. Silvio, "The information needs and information seeking behavior of immigrant southern Sudanese youth in the city of London, Ontario: an exploratory study," Library Review, 55(4), 2006. www.emeraldinsight.com/00242535.htm

[4] G. Orange \& V. Seitz, "Information Dissemination Needs of Indonesian Migrant Domestic Workers in Malaysia," Journal of Southeast Asian Research, (2012) 2012. http://www.ibimapublishing.com/journals/ JSAR/2012/492902/a492902.html

[5] Y. Jonsson-Lanevska, "The gate to understanding: Swedish libraries and immigrants," New World Library, 106(3/4), 2005.http://www.emeraldinsight.com/doi/ pdfplus/10.1108/03074800510587345

[6] C. Bitso, "An analysis of information-seeking behavior of geography teachers for information service intervention," Information Research, 17(4).

http://informationr.net/ir/17-4/paper549.html

[7] Ahmad Bakeri Abu Bakar, "Information seeking behaviors of rural women in Malaysia," Library Philosophy and Practice 2011.

http://digitalcommons.unl.edu/libphilprac/461

[8] C. Cole, "Information Need: A Theory Connecting Information Search to Knowledge Formation," The Canadian Journal of Library and Information Practice and Research, 7(2), 2012.

[9] ILO, "Indonesian Migrant Domestic Workers, Long Way Home,” Jakarta: International Labour Office, 2006.

[10] MFA, "Migrants and rights in Malaysia," 2006. http://www.mfasia.org/mfaStatements/Statement46MigrantsAndRightsInMalaysia.html

[11] H. Romdiati, M. Noveria \& S. Bandiyono (Eds.), 'Kebutuhan Informasi Bagi Tenaga Kerja Migran Indonesia: Studi Kasus di Propinsi Jawa Barat,' Kalimantan Timur dan Riau, Jakarta: Pusat Penelitian Kependudukan - Lembaga Ilmu Pengetahuan Indonesia (PPK-LIPI) 2002.

[12] K. E. Fisher, J. C. Durrance \& M. B. Hinton, "Information grounds and use of need-based services by immigrants in Queens, NY: A context-based, outcome evaluation approach. Journal of the American Society for Information Science \& Technology, 55.8, 754-766, 2004.

[13] Butcher, A.P., Soonley, P., \& Trlin, A.D. (2006). Being accepted: The experience of discrimination and social exclusion by immigrants and refugees in New Zealand. Occasional publication no. 13. New Setlers Programme. Massey University: Palmerston North, New Zealand. 
[14] K. E. Fisher, "Information behavior of Migrant Hispanic Farm Workers and Their Families in the Pacific Northwest" Information Research, 10(1) paper 199, 2004. http://InformationR.net/ir/10-1/paper199.html

[15] R. Savolainen, "Everyday Information Practices: A Social Phenomenological Perspective," The Scarecrow Press, Lanham, MD, 2008

[16] E. Frante, "Breaking the Isolation: Access to Information and Media among Migrant Domestic Workers in Jordan and Lebanon. Open Society Foundation, 2008. http://www.opensocietyfoundations.org/sites/default/files/ migrant-workers-information-report-20140223.pdf

[17] Momodu, M. O. (2002). Information needs and information seeking behavior of rural dwellers in Nigeria: a case study of Ekpoma in Esan West local government area of Edo State, Nigeria. Library Review, 51(8), 406410.

[18] A. Kaur, "Mobility, Labour Migration and Border Controls in Asia, Basingstoke and New York: Palgrave Macmillan, (2006).

[19] Aman Hossain \& Shariful Islam, "Information needs of rural women: A study of three villages of Bangladesh," Library Philosophy and Practice (e-journal), 2012. http://digitalcommons.unl.edu/libphilprac/693

[20] Mohammad Fazli Baharuddin \& Mohd Sharif Mohd Saad, "The Role of Teacher-Librarians and Information Literacy: A Case of Four MARA Junior Science Colleges in Kedah, Malaysia". Proceeding of 2013 IEEE Symposium on Business, Engineering and Industrial Applications, Sarawak, Malaysia, 2013.

[21] Mohammad Fazli Baharuddin, Mohd Sharif Mohd Saad \& Wan Mohd Hafiz Wan Hasnol. "Collaboration of School Teachers and Teacher-Librarians: A Study of Teachers' Perceptions". Proceedings of the 23rd International Business Information Management Association Conference (IBIMA 23th), Valencia, Spain, 2014. 